\title{
Amerikanische Unterhaltungsliteratur im I9. Jahrhundert: Von der Captivity Narrative zur Dime Novel ${ }^{1}$
}

\author{
Von Karl Heinz Göller (Regensburg)
}

\section{ABSTRACT}

Eine genuin amerikanische Unterabteilung der Chapbooks waren die sog. captivity narratives, Berichte über die Gefangennahme und Verschleppung weißer Siedler durch Indianer. Literarische Nachfahren der captivities waren die Dime Novel-Westerns. Sie brachten exemplarisch die Bedeutung des amerikanischen Westens und der frontier auf eine für die Selbstverwirklichung des Amerikaners einflußreiche Formel.

The so-called captivity narratives, i.e. reports describing the capture and carrying off of white settlers by Red Indians, were a genuine American sub-division of the chapbook genre. The Dime Novel Westerns were the literary successors of these captivities. They reduced the significance of the American West and the frontier to a formula which has acquired great importance for the self-realisation of the Americans.

Mit populärer amerikanischer Unterhaltungsliteratur im 19. Jahrhundert haben sich Literaturwissenschaftler entweder überhaupt nicht oder nur sehr pauschal auseinandergesetzt. Es gibt einige historische, kulturgeschichtliche und bibliographische Arbeiten zu Chapbooks und Dime Novels, aber so gut wie keine ernst $z u$ nehmenden literaturwissenschaftlichen Untersuchungen. Das liegt $z$. T. daran, daß diese Genres als Subliteratur und damit als bestenfalls literatursoziologisch interessant angesehen. wurden. Außerdem aber waren Chapbooks und Dime Novels für die Forschung nahezu unzugänglich; kaum eine Bibliothek der Welt hielt es für nötig, sie zu sammeln. Mittlerweile ist es gelungen, zuständige Stellen in den USA davon zu überzeugen, daß es sich bei den erhaltenen Kollektionen, insbesondere derjenigen der Library of Congress, um ein bislang verkanntes und unterschätztes kulturelles Erbe der Vereinigten Staaten handelt, das zu unserer Kenntnis der Geistesgeschichte des 19. Jahrhunderts ebenso viel beitragen kann wie die historische Literatur. Es setzt sich allmählich die Auffassung durch, daß volkstümliche Unterhaltungsliteratur nicht nur ein Spiegel der Auffassungen und Tendenzen ihrer Zeit ist, sondern diese Zeit auch mit beeinflußte und formte. ${ }^{2}$

${ }^{1}$ Das Forschungsprojekt Dime Novel wurde aus Mitteln der DFG unterstützt, wofür an dieser Stelle herzlich gedankt wird.

: Vgl. John A. Hayes, A Catalog of Dime Novel Material, including a section on Bufjalo Bill (1936), S. I. 
Das Chapbook war in England und in Amerika die erste gedruckte Literatur breit gestreuter Leserschichten ${ }^{3}$ und gilt auch als erste voll kommerzialisierte Unterhaltungsliteratur. Ein Chapbook bestand aus einem Bogen zu 24 Seiten, wurde in hohen Auflagen gedruckt und von fliegenden Händlern (chapmen) verkauft. Die bedeutendsten Sammlungen amerikanischer Chapbooks befinden sich in der Newberry Library (Chicago), der New York Public Library, der John Carter Brown Library sowie der Library of Congress.

Eine Unterabteilung bilden die sog. Captivity Narratives. Dabei handelt es sich um volkstümliche Erzählungen über die Gefangennahme und Verschleppung weißer Siedler (meist Frauen) durch Indianer, Gewaltmärsche durch die Wildnis, Aufenthalt im Indianerlager, Verkauf gegen Lösegeld oder Flucht und glückliche Rückkehr.

Blütezeit der Captivities war das I 8. und frühe 19. Jahrhundert. Obwohl Nachfahren des Genre bis Anfang des 20. Jahrhunderts nachweisbar sind, darf man annehmen, daß die Captivities durch die sog. Dime Novels abgelöst und ersetzt worden sind. Sie richteten sich an ähnliche Leserschichten wie die Chapbooks und befriedigten auch ähnliche Bedürfnisse.

Unter dem Oberbegriff Dime Novel werden alle in Serie erschienenen Heftchen und Bücher zusammengefaßt, die zwischen 1860 und 1910 in Amerika für einen "dime" (= 10 cents) oder auch einen "nickel" (= cents) verkauft wurden, einen in sich abgeschlossenen Roman bzw. eine Erzählung enthalten und in erster Linie unterhalten sollten. ${ }^{4}$ Von den acht gröBeren Dime Novel-Kollektionen in den USA befindet sich die umfangreichste in der Library of Congress. Nach Auskunft des Chief Librarian (Robert H. Land) besteht sie aus 19. $\$ 43$ separaten Einzeltiteln; möglicherweise sind es jedoch weit mehr. ${ }^{5}$

3 "...chapbooks were the first printed literature of the comnon pesple," A:t. "Chapbook" in: The American People's Encyclopedia, Bd. IV (1971), S. 44J.

${ }^{4}$ Gelegentlich werden Serien aus Gründen des Formats nicht zu den Dime Novels gerechnet. W. C. Miller, Dime Novel Authors, I 860-1900 (1930), o.P., spricht von "pocket size and large novels (folio), not classed as dime novels."

${ }^{5} \mathrm{Mr}$. Land verwies mich auf den Guide to Special Collections in the Library of Congress (1 949) sowie auf die dritte Auflage der Subject Collections ( 1 967), Stichwort "Dime Novel" (Brief des Chief Librarian Robert H. Land vom I 2. 2. 1974). In der Rare Books Division ist man daron überzeugt, daß diese Zahl zu tief angesetzt ist. Der Direktor der Rare Books Division, Dr. Mattheson, schätzt die Sammlung auf 40.000 separate Titel. In einem Brief an einen Senator vom 10.7. 1975 nannte ein anderer Chief Librarian die Zahl von etwa 40-50.000 Titeln (Paul L. Berry, Director, an Senator Edward Kennedy). Genauere Schätzungen oder Zählungen sind allerdings unmöglich, da die Serien meist zu Bündeln von zwanzig bis dreißig 
II.

Frederick Jackson Turner, der Historiker der amerikanischen frontier, schrieb: "American democracy is fundamentally the outcome of the experiences of the American people in dealing with the West." 6 Von diesem Erlebnis handeln die Captivity Narratives und ein Teil der Dime Novels; nur unter diesem Gesichtspunkt sollen sie im folgenden untersucht werden. Insbesondere möchte ich den Prozeß der Literarisierung der Eroberung des Westens in einigen wesentlichen Punkten darstellen. Ein Überblick über die beiden Gattungen ist im Rahmen dieses Aufsatzes nicht möglich und wird auch nicht versucht.

Die Captivity Narratives sind eine Art Vorläufer der Dime Novels; ${ }^{7}$ sie bereiten deren Stoffe und Motive vor und weisen erstaunliche Parallelen im Hinblick auf deren Wirklichkeitsdarstellung auf. Die frühesten Berichte über Kontakte mit Indianern überraschen den heutigen Leser durch ihre meist positive Einschätzung der roten Rasse. Interessant sind in diesem Zusammenhang besonders die Berichte von Missionaren verschiedenster Denominationen, die schon früh versucht hatten, die Indianer zu bekehren. Dabei kam es zu freundschaftlichen Kontakten zwischen Weißen und Roten. Die Missionare sahen im Indianer nicht das blutrünstige Tier, sondern den Bruder, der ihrer Fürbitte und Bekehrung bedurfte.

Heften zusammengeschnürt sind, zum guten Teil in unregelmäßiger Reihenfolge; kaum eine einzige Serie ist komplett. Die einzelnen Romantitel sind nicht katalogisiert. Es gibt lediglich eine Liste der verschiedenen Serien: "Series in their order as on the shelf, numbered for easy reference." Diese Liste enthält 267 Serien ("Adventure Series" bis "Seaside Library"). Von Beadle, dem bedeutendsten Verleger von Dime Novels im I9. Jahrhundert (vgl. dazu A. Johannsen, The House of Beadle and Adams and Its Dime and Nickel Novels. The Story of a Vanished Literature, 3 Bde., plus Supplementbd. (1950, Supp. 1962), sind allein vierzig verschiedene Serien aufgeführt (I. Beadle's American Battles bis 40. Beadle's Waverly Library). Einzelne dieser Serien enthalten mehr als tausend Titel, so z. B. Beadle's Dime Library. Die gesamte Sammlung befindet sich in cinem schlechten Zustand. Ganze Serien sind bereits so stark verfallen, daß sie nicht mehr aus dem Magazin geholt, geschweige denn gelesen werden können. Die Reproduktion der Serien im Xeroxverfahren bzw. die Aufnahme auf Microfilm wäre nur möglich, wenn eine chemische Konservierung vorgenommen würde bzw. wenn man sich damit abfände, daß die Originale durch die Reproduktion zerstört werden.

'F. J. Turner, "Contributions of the West to American Democracy," in: R. A. Billington, ed., Frontier and Section, Selected Essays of Frederick Jackson Turner (1 961), S. 95. (Dieser Artikel wurde ursprünglich publiziert in Atlantic Montbly, 9r (January I 903), 83-96.)

"Roy Harvey Pearce nennt die Captivity Narrative "the eighteenth-century equivalent to the dime novel." "The Significances of the Captivity Narrative," American Literature, I9 (1947/48), i 3. 
Zunächst waren auch die Beziehungen zwischen anderen Weißen und Indianern keineswegs feindselig. Die Weißen sahen bald, daß sie für das Leben in der Wildnis von den Indianern lernen konnten. Sie bewunderten deren natürlichen, von der Zivilisation unbeeinflußten Lebensstil. Die Captivities bezeugen, daß manchmal sogar eine Art umgekehrter Missionierung stattgefurden hat. Die Indianer belehrten die Weißen darüber, daß die Rothäute infolge ihrer Armut die Vatergüte Gottes besser verstehen und würdigen könnten als der im Überfluß lebende Weiße.

Brother, - Owaneeyo (= God) sometimes suffers us to be in want, in order to teach us our dependence upon him, and to let us know that we are to love and serve him; and likewise to know the worth of the favors that we receive, and to make us more thankful. ${ }^{8}$

Bedeutsam ist, daß Berichte dieser Art chronologisch vor der stärker fiktionalen Literatur liegen und als historisch-faktische Darstellungen wahrscheinlich nicht allzu weit von der Wirklichkeit entfernt sind, wie sich aus gelegentlich beigefügten affidavits entnehmen läßt. ${ }^{9}$ Tatsächlich haben Indianer während des 18 . Jahrhunderts oft weiße Kinder und Erwachsene adoptiert, um Kriegsverluste auszugleichen. Viele Weiße wurden derart in indianische Stämme integriert, daß sie sich später weigerten, zu ihren weißen Landsleuten zurückzukehren. Crèvecoeur, einer der Bannerträger des Primitivismus, war davon überzeugt, daß die indianische Lebensart dem Menschen und damit auch dem Weißen kongenial sei. ${ }^{10}$

Die Literarisierung der Captivities findet jedoch schon recht früh statt. Das Genre befriedigte wahrscheinlich von Anfang an bei dem soeben dem Analphabetentum entwachsenen Publikum ähnliche Bedürfnisse wie die moderne Unterhaltungsliteratur beim heutigen Leser. Daher weist das Genre Captivity eine Entwicklung auf, die in wesentlichen Punkten parallel zur Entwicklung erzählender Literatur generell, vor allem des Romans zu sehen ist.

So fällt schon bei oberflächlicher Lektüre auf, daß die frühen Captivities ähnlich wie Bunyans Pilgrim's Progress das Leben in der neuen Welt, ins-

s An account of the remarkable occurrences in the life and travels of Colonel James Smith, (late a citizen of Bourbon County, Kentucky) during his captivity with the Indians, Philadelphia: J. Grigg, No 9, N. Fourth Street, 1831. Zit. in: Phillips D. Carleton, "The Indian Captivity," American Literature, Is (1943/44), 175.

${ }^{9}$ Vgl. dazu Phillips D. Carleton, "The Indian Captivity," American Literature, Is (I $943 / 44)$, I 69 .

${ }^{10} \mathrm{Vgl}$. Hector S. John de Crèvecoeur, Letters from an American Farmer (1 782 ), ed. W. B. Blake, Everyman's Library, 640 (1962), S. 215 : “There must be something more congenial to our native dispositions [in Indian life], than the fictitious society in which we live; or else why should children, and even grown persons, become in a short time so invincibly attached to it." 
besondere die Reise durch die Wildnis, als peregrinatio animae (= Reise der menschlichen Seele zu Gott) schildern. Alle Drangsale und Unglücksfälle werden als Prüfungen angesehen, die Gott in seiner unerforschlichen Weisheit den Menschen auf dem Wege zum himmlischen Jerusalem auferlegt." Auch die eigentliche "Captivity" wird als religiöses Erlebnis gedeutet. Gelegentlich schildern ehemalige Gefangene ihren vorübergehenden Aufenthalt bei den Wilden als eine Art descensus ad inferos. Mrs. Rowlandson z. B. bezeichnet das Indianerdorf als Hölle und die Indianer als Teufel. ${ }^{12}$

Aus diesem Grunde konnte sich offensichtlich das Bild von der "edlen Rothaut" in der Literatur nicht durchsetzen. Wenn in frühen Publikationen die Indianersiedlung als Hölle und die Indianer als Teufel bezeichnet wurden, so waren die Autoren primär an den religiösen Implikationen für das eigene Seelenheil interessiert. Bedauerliches Nebenergebnis aber war, daß die puritanischen Prediger ${ }^{13}$ zur Verteufelung der roten Rasse beitrugen, statt Liebe $\mathrm{Haß}$ säten und die Beziehungen zwischen Einwanderern und Eingeborenen vergifteten.

Ähnlich gewinnen die "Indian haters" auch in der Literatur die Oberhand. ${ }^{14}$ In den späteren Captivities werden fast nur noch Grausamkeit und Unmenschlichkeit der Indianer dargestellt. Selbst aus den Titeln läßt sich diese Entwicklung belegen:

Eine erzeblung von den trübsalen und der wunderbabren befreyung so gescheben an William Flemming und dessen Weib Elisabeth, welche bey dem verwichenen einfall der Indianer über die einwohner im großen Wald (Grät Grov) bei Cannagodschick in Pensilvanien sind gefangen genommen worden. Nach ihrer eigenen Aussage. 2 ed. $\mathrm{Zu}$

${ }^{11} \mathrm{Vgl}$. John Williams, Redeemed Captive Returning to Zion (1707) (1908).

${ }^{12}$ The Narrative of the Captivity and Restoration of Mrs. Mary Rowlandson (1930), S. $9-10$.

${ }^{13} \mathrm{Vgl}$. dazu z. B. Cotton Mather, Magnalia Christi Americana; or,The Ecclesiastical History of New England ... in seven books (1702), Buch VI und VII: ed. Thomas Robbins (1852, repr. 1967), S. 357 ff., v.a. S. 357-36r und 634-636.

${ }^{14}$ Eine interessante Zwischenstellung nimmt dabei noch ein 1802 erschienenes Chapbook ein, The Captive American; containing an Account of the sufferings of Mrs. Jobnson, during four years with the Indians and French (Air, printed by J. \& P. Wilson, 1802 ). In diesem Chapbook lassen sich zwei verschiedene Haltungen dem Indianer gegenüber feststellen: die (ältere) primitivistische, positive Haltung und die (jüngere) puritanische, indianerfeindliche Haltung. Beide Traditionsstränge überlagern sich in diesem Chapbook, ohne daß sie vom Erzähler bzw. der Erzählerin zur Deckung gebracht, d.h. episch integriert werden. Interessant an diesem Chapbook ist außerdem auch, wie auf dem Titelblatt auf die (angebliche) Authentizität der geschilderten Erlebnisse der Mrs. Johnson verwiesen wird: "The author, Mrs. Johnson, now Mrs. Hastings, is still living in Charlestown, Newhampshire (sic!) and first published her Narrative at Walpole in Newhampshire, in the year 1796. - The sufferings she met with during her captivity, she bore with a degree of magnanimity that will astonish the reader while he peruses the following pages." 
Läncester gedruckt von W.Duglas und ins teutsche übersetzt, und gedruckt zu Germanton bey Christoph Saur, 1756. Auch zu haben bey David Däschler zu Philad. (sic!) ${ }^{15}$

oder:

Narrative of the tragicai death of Mr. Darius Barber, and bis seven Cbilitren, who were inhumanly butchered by the Indians, in Camden County, Georgia, January 26, I 818 . To which is added the account of the captivity and sufferings of Mrs. Barber. Boston, Printed for David Hazen I $818 .{ }^{16}$

Die Autoren schwelgen geradezu in den von Indianern begangenen Grausamkeiten, deren Authentizität damals zwar immer wieder behauptet aber auch häufig geleugnet wurde. ${ }^{17}$ Natürlich sind zahlreiche Berichte über Folterungen, Ermordungen und Grausamkeiten aller Art durch Augenzeugenberichte belegt; die meisten aber machen den Eindruck literarischer Fiktion, etwa zum Erweis der Notwendigkeit, alle Indianer zu töten. ${ }^{18}$ Brackenridge schrieb in einem Vorwort zu Knights und Slovers Expeditionsbericht:

...these Narratives may be serviceable to induce our government to take some effectual steps to chastise and suppress them [ = the red Indians]; as from hence they will see that the nature of an Indian is fierce and cruel, and that an extirpation of them should be useful to the world and honorable to those who can effect it. ${ }^{19}$

15 Verfasser dieser Erzählung ist William Fleming. Die englische Version dieser Captivity trägt folgenden Titel: $A$ narrative of the sufferings and surprizing deliverance of William and Elizabeth Fleming, who were taken captive by Capt. Jacob, Commander of the Indians, who lately made an excursion on the inhabitants of Great-Cove, near Conecochieg, in Pennsylvania, as related by themselves. Philadelphia: Printed by James Chattin, for the benefit of the unhappy sufferers. 1756. Price $6 \mathrm{~d}$. Vgl. dazu das Faksimile des Titelblattes in H. B. Weiss, A Book about Chapbooks. The People's Literature of Bygone Times (1942, repr. 1969), S. 1 30.

${ }_{16}$ Verfasserin ist Mrs. Eunice Barbcr.

17 Vgl. dazu z. B. Samuel Gardner Drake, Tragedies of the wilderness; or, True and autbentic narrative of captives, who have been carried away by the Indians from the various frontier settlements of the Unitcd States, from the earliest to the present time. Illustrating the manners and the customs, barbarous rites and ceremonies, of the North American Indians and their various methods of torture practised upon such as have, from time to time, fallen into their hands (Boston, Antiquarian bookstore and institute, I 844).

${ }^{18} \mathrm{Vgl}$. dazu z. B. The surprising bistory of Peter Williamson ... giving an account of his birth and parentage..., also, a relation of his marriage with a planter's daughter, and how the wild savages came to his plantation one night and burnt his house and took him captive, and also a descriptson (sic!) of his sufferings while with them, their great cruelties, and the manner of his escape (Stirling, printed and sold by C. Randall, I 803 ).

19 "Narrative of a Late Expedition Against the Indians, with an Account of the Barbarous Execution of Col. Crawford and the Wonderful Escape of Dr. Knight 
Natürlich darf man solch blutrünstige Genozid-Wünsche nicht bei allen vermuten, die über indianische Grausamkeiten berichten. Die meisten schwrelgen in erdachten oder von Augenzeugen berichteten Scheußlichkeiten in gleicher Weise wie die englischen Romanautoren in gotbic horrors. Daher hat man in den Captivities zu Recht ein amerikanisches Äquivalent der Gothic Novel gesehen. ${ }^{20}$ Schon Charles Brockden Brown erkannte scharfblickend, daß der Schauerroman auf den Leser emotional wirken möchte und dafür ein Arsenal verschiedener Requisiten zur Verfügung hat. In Amerika, so sagt Brown, bedarf es keiner gotischen Schlösser und Folterkammern, um das Mitgefühl des Lesers zu gewinnen. Amerika hat für diesen Zweck eigene Kulissen: "The incidents of Indian hostility, and the perils of the Western wilderness." 21

Charles Brockden Brown erkannte die typologischen Ähnlichkeiten von Gothic Novel und Captivity Narrative. Genetische Verbindungslinien gibt es wohl kaum. Die ersten Autoren von Captivities waren Analphabeten, die ihre Geschichten berufsmäßigen Schreibern diktierten. Zu einem populären literarischen Genre wurden die Erzählungen erst, als Literaten aufgrund der Beliebtheit der authentischen Captivities selbst solche Geschichten ersannen. Wie in den meisten anderen literarischen Gattungen sind die Epigonen nur schwer von den Originalen zu unterscheiden, vor allem deshalb, weil die Autoren ihre Geschichten ganz bewußt im Stil der Pioniere erzählen. Nach I 800 allerdings reichen die vergleichsweise bescheidenen Greuel der frühen Captivities nicht mehr aus. Ähnlich wie in bestimmten Gothic Novels werden nun Grausamkeiten zuvor unbekannter Art erfunden und in den Narratives einem stärker städtischen Publikum vorgelegt. Die Autoren sind nicht meht an der frontier, dem Erlebnis der Wildnis oder dem Kontakt mit den Wilden interessiert, sondern nur noch an der Anhäufung von Horror: der tbriller ist geboren.

Natürlich gab es auch im 19. Jahrhundert noch authentische CapitivityErzählungen, die von den Beteiligten selbst niedergeschrieben oder einem Schreiber in die Feder diktiert wurden. Es gab auch Sammlungen solcher Captivities, bei denen die Herausgeber peinlich darauf achteten, daß nur echte (authentische) Geschichten aufgenommen wurden, die nachweisbar auf die Gefangenen selbst zurückgingen. Ein Beispiel dafür ist Samuel

and John Slover from Captivity in 1782," Freeman's Journal or, North American Intelligencer, April 30, May 7, 14, 28, I783. Im gleichen Jahr auch in Philadelphia (bei F.Bailey) erschienen.

${ }^{20}$ Roy Harvey Pearce, "The Significances of the Captivity Narrative," American Literature, I9 (I 947/48), I4f.

${ }^{21}$ C. B. Brown, Edgar Huntly; or, Memoirs of a Sleep-Walker, Preface (1887, repr. 1970), S. 4 . 
Gardner Drakes Tragedies of the wilderness; or, True and autbentic narratives of captives. ${ }^{22}$

Die meisten Captivity Narratives sind fiction. Das wird besonders deutlich aus einem Seitenzweig dieses literarischen Typs, den man "sentimental captivity" nennen könnte.

Besonders bekannt und beliebt war in den letzten Jahrzehnten des 18 . Jahrhunderts ein Chapbook von Abraham Panther: A very surprising narrative of a young woman, discovered in a rocky cave, after having been taken by savage Indians of the wilderness, in the year 1777 , and seeing no human being for the space of nine years... etc. ${ }^{23}$ Seit längerer Zeit ist man sich darüber einig, daß es sich bei dieser Geschichte nicht um eine bona-fide captivity handelt, sondern um Fiktion. Die Geschichte wurde erfunden wie die späteren Dime Novels und als historisch-faktisch einem Publikum verkauft, das an Fiktion noch nicht gewöhnt war und daher "Fakten" vorzog. ${ }^{24}$

Anklänge an die Empfindsamkeit finden sich schon im Titel solcher Erzählungen, und zwar in Begriffen wie "melancholy," "affecting," "tragical," vor allem aber in Hinweisen auf die erlittenen Qualen und die daraus erschließbare Seelengröße der Frauen:

Massy Harbison (White), A Narrative of the sufferings of Massy Harbison, from Indian barbarity, giving an account of her captivity, the murder of her two children, her escape, with an infant at her breast; together with some account of the cruelties of the Indians, on the Allegheny River \& c. during the years $1790,1,2$, 3, 4. Communicated by herself (Pittsburgh, I 828);

Arthur Bradman, A narrative of the extraordinary sufferings of $M r$. Robert Forbes, bis wife and five children; during an unfortunate journey through the wilderness, from Canada to Quennebec River, in the year 1784 : in which three of their children were starved to death. [Taken partly from their own mouths, and partly from an imperfect journal and published at their request.] (Philadelphia, Printed for M. Carey, 1794, repr. Tarrytown, N.Y., W.Abbat, 1917);

Thomas Barry, Narrative of the singular adventures and captivity of Mr. Thomas Barry, among the Monsipi Indians, in the unexplored regions of North America, during the years 1797,1798 \& 1799 , including the manners, customs \& c. of that tribe; also a particular account of his escape, accompanied by an Indian female: the extraordinary hardships they encountered; and their safe arrival in London. Written by himself (Sommers Town: Printed and published by A. Neil, I 800);

Thomas Baldwin, Narrative of the massacre, by the savages, of the wife \& chilitre: of Tbomas Baldwin, who, since the melancholy period of the destruction of his unfortunate family, has dwelt entirely alone, in a hut of his own construction secluded

${ }^{22}$ Vgl. oben Anm. I7.

${ }^{23}$ Der vollständige Text hrsg. von R.W.G. Vail, "The Abraham Panther Indian Capitivity, With a Bibliographical Introduction," American Book Collector, 2 (August-September 1932), I65-172.

${ }^{24}$ Vgl. Harry B. Weiss, American Chapbooks (1938), S. 16. 
from human society in the extreme western part of the State of Kentucky (New York, Martin \& Perry, 1837);

An affecting narrative of the captivity and sufferings of Mrs. Mary Smith, who, with her husband and three daughters were taken prisoners by the Indians, in August last [18I4] and after enduring the most cruel hardships and torture of mind for sixty days (in which time she witnessed the tragical death of her husband and helpless children) was fortunately rescued from the merciless hands of the savages by a detached party from the army of the brave General Jackson, now commanding at New Orleans (Providence, printed for L.Scott [18I5]);

The affecting bistory of Mrs. Howl, the wife of a British officer in America, who after seeing her husband murdered, was, with her seven children, seized by the Indians, and carried by them many hundred miles to the country of their tribe; and atter enduring shocking hardships, by the intervention of Providence, was restored to her country. Interspersed with an exact account of the brutal manners, horrid customs and monstrous barbarities of the savages of America (London, printed and sold by J. Bailey, I 8 I5).

Aus den Protagonisten und Titeln, aber auch aus Stil und Aufbau dieser Captivities können wir schließen, daß sie sich in erster Linie an ein weibliches Lesepublikum richteten. Die Autoren drücken auf die Tränendrüse, vor allem bei der fast zum Klischee gewordenen Ermordung des Kleinkindes, das brutal aus den Armen der Mutter gerissen und skalpiert wird, dabei aber aus unerfindlichen Gründen lacht - manchmal sogar noch nach vollzogener Skalpierung. ${ }^{25}$ Ein weiteres inhaltliches Merkmal der Gattung sind Gewaltmärsche über riesige Entfernungen hinweg, wobei die Protagonistin meist schwanger ist.

Die Männer spielen in diesen Geschichten entweder gar keine oder eine unrühmliche Rolle. Bestenfalls richten sie ihr brechendes Auge voll Trauer und Schmerz auf die zurückgelassene Frau, der sie nicht mehr helfen können, und begleiten diesen Blick mit herzzerreißendem Stöhnen. ${ }^{26}$ Aber meist hat der Autor die Männer zuvor aus dem Wege geräumt. In einer Captivity verlassen alle Männer das Haus ("they were gone out of the way," wie Elizabeth Hanson ${ }^{27}$ sich ausdrückt), obwohl elf Indianer auf den Fel-

25. "Gracious God! What a scene presented itself to me! My child, scalped and slaughtered, smiled even then,..." A True Narrative of the Sufferings of Mary Kinnan (Elizabethtown, I 795), S. 5, zit. in: Roy Harvey Pearce, “The Significances," S. Io.

26 "...my husband, scalped and weltering in his blood, fixed on me his dying eye, which, though languid, still expressed an apprehension for my safety, and sorrow at his inability to assist me; and accompanied the look with a groan that went through my heart." A True Narrative of the Sufferings of Mary Kinnan (1795), S. 5, zit. bei Roy Harvey Pearce, a.a.O., S. Io.

${ }^{27}$ An account of the captivity of Elizabeth Hanson, now or late of Kachecky, in NewEngland: who, with four of her children and servant maid, was taken captive by the Indians, and carried into Canada. Setting forth the various remarkable occurrences, sore trials, and wonderful deliverances which befel them after their departure, to the time of their redemption. Taken in substance from her own mouth, 
dern herumlauern ("who had been skulking in the fields"). Sie müssen fort, weil die weibliche Seelengröße dargestellt werden soll. So gerät ein gewisser John Williams, Geistlicher in Deerfield, zusammen mit seinen Pfarrkindern in Gefangenschaft. Auf dem langen Marsch nach Kanada wird er von einer jungen Frau katechisiert, die nach Verletzungen eine Fehlgeburt hatte und nun weiß, daß die Indianer sie wegen ihrer Transportunfähigkeit töten werden. Sie zeigt dem Geistlichen, was Seelengröße ist: "I am not afraid of death; I can, through the grace of God, cheerfully submit to his will." 28

Eine Art Index und Zusammenfassung der wesentlichsten Züge der amerikanischen Captivity Narratives ist die Geschichte der Maria Kittle von Ann Eliza Bleecker ( 1793 ). Hier finden wir sämtliche Elemente der Captivity - von den teuflischen Indianern über die heldenmütigen Frauen sowie die ungeschickt-gefühllosen Männer zu den trotz Skalpierung lächelnden Babies. Die Art der Darstellung aber sowie der Umfang der Captivity (etwa 70 Druckseiten) nähern das Werk bereits der Dime Novel an.

Wenige Jahre später erschienen die ersten Parodien von Captivities; sie weisen allerdings kaum noch triviale Züge auf, sind vielleicht nicht einmal mehr zur reinen Unterhaltungsliteratur zu rechnen. Ein Beispiel ist "Jemima O'Keefy. - A Sentimental Tale" von Timothy Flint. ${ }^{29}$ Jemima, eine Amerikanerin irischer Herkunft, heiratet den reichen Pennsylvanien-Deutschen Jacob Barndollar. Bei einem Úberfall wird Jemima von Indianern geraubt und fünf Jahre lang in einem Shawnee-Dorf festgehalten. Schließlich gelingt ihr die Flucht, und sie kehrt zu Jacob zurück, der aber inzwischen mit Joan Windpuffer verheiratet ist. Jemima ist in Jacobs Haus überflüssig - zwei Frauen kann der Deutsche nicht gebrauchen - sie kehrt daher $z u$ den Indianern zurück und heiratet den Häuptling.

"Sentimental" ist Jemima also keineswegs. Der Autor deutet an, daß der ehrsame Jacob bereits seine liebe Last mit der Irin hatte - und gibt augenzwinkernd zu verstehen, daß der Indianerhäuptling nichts zu lachen haben wird. Die Indianer stehen also als "Minderheit" auf einer Stufe mit Iren und Deutschen; das geht auch daraus hervor, daß Jemima den Indianerhäuptling zum Ehemann nimmt - man stelle sich vor, wie Maria Kittle auf eine solche Möglichkeit der Lösung von Eheproblemen reagiert hätte! Flint sieht in den Indianern in erster Linie Menschen, nicht aber Teufel und Untiere wie die traditionellen Captivity-Autoren.

by Samuel Bownas (London: printed and sold by Samuel Clark ... MDCCLX $[1-60])$, zit. in: Phillips D. Carleton, "The Indian Captivity," American Literature, Is (1 943/44), I 77; vgl. dazu auch Roy Harvey Pearce, a.a.O., S. 4-6.

${ }^{28}$ Zitat bei Phillips D. Carleton, a.a.O., S. 177, ohne Nachweis der Quelle.

29 "Jemima O'Keefy. - A Sentimental Tale," The Western Monthly Review, I (November, 1827), 384-393. Zit. in: J.K.Folsom, Timothy Flint (1965), S. 182; dazu auch J.K. Folsom, a.a.O., S. $7 \mathrm{I}-73$. 
III.

Die Dime Novels waren zwar weit verbreitet und beliebt, aber nicht angesehen. Erastus Beadle, sicherlich der bedeutendste Verleger von Dime Novels, galt allgemein als Produzent von Schundliteratur, die eigentlich hätte verboten werden müssen, da sie angeblich Moral und Sitten der Jugend verdarb. Der heutige Kritiker fragt sich allerdings, woran die damaligen Pädagogen und Morallehrer Anstoß nahmen. Beadles Programm, das er in Anweisungen an die Autoren bekanntmachte, ${ }^{30}$ stand nicht nur auf dem Papier, sondern wurde rigoros durchgesetzt. ${ }^{31}$ Wahrscheinlich begnügten sich die Pädagogen damals damit, die "Schundliteratur" mit den gelben Umschlägen einzusammeln und zu vernichten, ebenso wie Lehrer heute Jerry Cotton-Hefte aus dem Verkehr ziehen. Häufig haben sie diese Literatur nicht durch eigene Lektüre kennengelernt.

Eigentlich hätten die Lehrer Dime Novels zur Lektüre empfehlen müssen. Diese Romane weichen nämlich niemals von ihrem verlegerisch festgelegten Moralkodex ab: die Tugend wird stets belohnt, Laster und Sünde werden bestraft. ${ }^{32}$ Beadle achtete darauf, daß auch die jüngere Generation Dime Novels lesen konnte, ohne Schaden zu nehmen. Außerdem kann die Dime Novel zu anderer Art von Literatur hinführen. Ähnlich wie Winnetou Geschmack auf weitere Bände von Karl May und andere Wildwest-Literatur macht, so wirkten die Dime Novels gewohnheitsbildend.

Außerdem waren die Bücher billig; der Preis war offensichtlich soziologisch richtig gewählt. Im Laufe der folgenden Jahrzehnte (bis etwa I910)

30 "Authors who write for our consideration will bear in mind that

We prohibit all things offensive to good taste, in expression or incident -

We prohibit subjects or characters that carry an immoral taint -

We prohibit the repetition of any occurrence, which, though true, is yet better untold -

We prohibit what cannot be read with satisfaction by every right-minded person - old and young alike -

We require your best work -

We require unquestioned originality -

We require pronounced strength of plot and high dramatic interest of story -

We require grace and precision of narrative style, and correctness in composition.

Authors must be familiar with characters and places which they introduce, nor attempt to write in fields of which they have no intimate knowledge. Those who fail to reach the standard here indicated cannot write acceptably for our several Libraries, or for any of our publications." Zit. in: E.Pearson, Dime Novels; or, Following an Old Trail in Popular Literature (1929, repr. I968), S. 96.

${ }^{31}$ Vgl. Edmund Pearson, a.a.O., S. 95: Bret Harts Roman Gabriel Conroy z. B. wurde von Beadle abgelehnt, weil er "zu sensationell" war.

${ }^{32}$ Vgl. dazu Della T. Lutes, "Erastus F. Beadle, Dime Novel King," New York History, 22 (April I94.I), Is2. 
kamen zwar zahlreiche weitere Serien heraus, von denen ein Heft je 20 bis 25 Cents kostete, sie hatten aber offenbar nicht denselben Erfolg. So erschienen zwischen I 871 und I 876 Beadle \& Adams 20 Cent-Novels, die den doppelten Umfang der normalen Dime Novels hatten, beim Publikum aber ebenfalls nicht ankamen. 1876 gaben die Verleger deshalb die Serie auf und versuchten es statt dessen mit der Half Dime Library, die mehr als 25 Jahre mit ständig steigendem Marktanteil verkauft wurde. Insgesamt umfaßte die Serie (mit Nachdrucken) mehr als tausend Titel und muß daher zu den erfolgreichsten Serien der amerikanischen Verlagsgeschichte gerechnet werden. Es wäre eine interessante Aufgabe, die Zahl der tatsächlich gedruckten Exemplare dieser Serie, der wahrscheinlich gelesenen und der verliehenen nachzurechnen. Ein solches Rechenexempel könnte klar machen, welch überragende Rolle diese Art von Literatur für die Erziehung und Meinungsbildung in Amerika gespielt haben muß.

Aus den meisten Äußerungen geht hervor, daß Autoren und Verleger nicht für eine bestimmte Klasse oder Schicht $z u$ arbeiten glaubten, sondern für ein Lesepublikum, das quer durch alle Schichten geht. Schon in der Verlagsnotiz von Beadle zur ersten Dime Novel hieß es:

By the publication of the series contemplated, it is hoped to reach all classes, old and young, male and female, in a manner at once to captivate and to enliven - to answer to the popular demand for works of romances, but also to instil a pure and elevating sentiment in the hearts and minds of the people. Beadle \& Co., New York, June, $1860 .{ }^{33}$

Daß Beadle mit der Behauptung des "popular demand" nach dieser Art Literatur Recht hatte, sollten die späteren Verkaufserfolge beweisen. Ob er allerdings wirklich alle Klassen der Bevölkerung mit seinen Büchern erreicht hat, ist heute kontrovers. In Amerika war es zwar für hohe Richter, Bankdirektoren und Präsidenten leichter als in Deutschland und England, sich zu Lektüre dieser Art zu bekennen, ${ }^{34}$ aber den Dime Novels haftet selbst heute noch in den USA das Stigma des Subliterarischen an, wie sich im Gespräch mit Bibliothekaren und Literaturwissenschaftlern meist bald herausstellt. Kaum jemals beruht jedoch die negative Einschätzung der

${ }^{33}$ "Publisher's Notice" in: A.S. Stephens, Malaeska. The Indian Wife of the White Hunter (1860, repr. 1929, repr. I971), o.P. [S. V].

${ }^{34}$ Vgl. dazu E. Pearson, a.a.O., S. 225-255, J.S. Cobb, A Plea for Old Cap Collier (I92I) und Albert Johannsen, a.a.O., Bd. I, S. 9.

Außerdem finden sich in zahlreichen Nummern des Dime Novel Round-up, ed. Edward T. LeBlanc Artikel über die Dime Novel-Begeisterung der Generation um I 860. Sekundärliteratur zu diesem Problem: Charles M. Harvey, "The Dime Novel in American Life," Atiantic Montbly, 100 (July 1907), 37-45; Henry Morton Robirson, "The Dime Novel Is Dead, but the Same Old Hungers Are Still Fed," 
Dime Novel auf eigener Lektüre, sondern fast immer auf überlieferten Vorurteilen.

Ein guter Teil der Dime Novel Westerns wurde von Verlegern und Autoren als romance bezeichnet, wobei sich manchmal der Verdacht einschleicht, $\mathrm{d} a ß$ damit nur auf eine in den plot mehr oder weniger gut integrierte Liebesgeschichte angespielt wird. Zu fragen wäre, ob auch die reinen Männergeschichten von Trappern, Goldgräbern, mountain men usw. romances genannt werden. Jedenfalls gibt es keinen Gegensatz zwischen romance und Wirklichkeit bzw. dem Wahrscheinlichen. Immer wieder betonen Verleger, Autoren und Kritiker, daß die dargestellten Fakten der historischen Wirklichkeit entsprechen. Häufig werden historische Personen namentlich aufgeführt bzw. mit der Haupt- oder Nebenhandlung verbunden. Auch Anspielungen auf historische Ereignisse sind nicht selten. Beadle selbst legte allergrößten Wert auf die verisimilitudo, d. h. ein wahrheitsgetreues Verhältnis zur Wirklichkeit. ${ }^{35}$ In Anzeigen wird immer wieder festgestellt, daß die Autoren die geschilderten Landschaften persönlich kennengelernt haben und aus eigener Erfahrung sprechen. ${ }^{36}$ Verisimilitudo scheint für die Verleger eines der am leichtesten erkennbaren Qualitätsmerkmale von Westernliteratur gewesen zu sein; je näher an der historischen Wirklichkeit, desto besser das Buch. Ähnlich behauptet auch die Nickel Library, daß die Wirklichkeit historisch treu nachgezeichnet werde. In der ersten Nummer verspricht der Verleger, die Hefte seien

of the best authority in respect to the traits of character and customs of the different tribes of red men that have or now inhabit (sic!) this country ... strictly correct in the descriptive point ... Stories of this character are always enjoyable on account of their consistency - their truthfulness as to historical events, and the vivid portrayal of the struggle of the early time pioneers. ${ }^{37}$

Die Autoren werden nicht selten als "Westerners" bezeichnet, die Land und Leute aus persönlicher Anschauung kennengelernt haben und folglich genau wissen, worüber sie schreiben. Manchmal werden Wörter wie Daguerrotypie verwendet, um darzulegen, daß die Wirklichkeit mit fotografischer Treue wiedergegeben worden ist. ${ }^{38}$ Diese Versicherungen wirken auf den modernen Kritiker ein wenig abwegig, zumindest übertrieben. Die

Century, A Popular Quarterly Magazine, I 16, i (May, I928), 60-67; Frank Luther Mott, "The Beadles and Their Novels," Palimpsest, 30 (June, 1 949), 173-189, v.a. 183 ff.; Mary Noel, "Dime Novels," American Heritage, N.S. (February, 1956), $50-55$, II 2-II3.

${ }^{35} \mathrm{Vgl}$. dazu Beadles Anweisungen an seine Autoren; s.o., Fußnote 30.

${ }^{36}$ I 862 heißt es in der Vorankündigung eines Romans von N.C.Irons, die Personen seien der historischen Wirklichkeit entnommen.

${ }^{37}$ Editorial im ersten Band der Nickel Library. 
Topographie des Westens macht durchwegs einen stereotypen, klischeeartigen Eindruck. Aufgrund der genannten Merkmale ist es kaum jemals möglich, Landschaften zu lokalisieren. Gelegentlich kommen allerdings recht genaue Ortsangaben vor, die eine Rekonstruktion von Expeditionswegen etc. ermöglichen. Generell aber ist die Natur nicht um ihrer selbst willen von Interesse.

Zahlreiche Autoren und Kritiker, wie etwa Simms, hatten eine genuinamerikanische Literatur verlangt und durch ihre eigene literarische Produktion den Weg gewiesen. ${ }^{39}$ Nur hat Simms Anhänger und Freunde gefunden, die zwar seinen Patriotismus, nicht aber sein Qualitätsbewußtsein teilten. Von der Avantgarde und den Literaturtheoretikern wurde Simms von vornherein abgelehnt - erst recht die Westernliteratur, die entsprechend seinen Forderungen entstand. Simms konnte nicht ahnen, daß seine Forderung durch eine wahre Sturzflut von Literatur erfüllt werden sollte. Aller-

${ }^{38}$ So z.B. in Verlagsanzeigen und Klappentexten.

${ }^{39}$ Vgl. W.G.Simms, The Yemassee (1835), ed. Alexander Cowie (1937): "The question briefly is - What are the standards of the modern Romance? ... The reply is immediate, The modern Romance is the substitute which the people of the present day offer for the ancient epic... When I say that our Romance is the substitute of modern times for the epic or the drama, I do not mean to say that they are exactly the same things, and yet, examined thoroughly, and (sic!) the differences between them are very slight. These differences depend on the material employed, rather than upon the particular mode in which it is used. The Romance is of loftier origin than the Novel. It approximates the poem. It may be described as an amalgam of the two. It is only with those who are apt to insist upon poetry as verse, and to confound rhyme with poetry, that the resemblance is unapparent. The standards of the Romance ... are very much those of the epic. It invests individuals with an absorbing interest ... it requires the same unities of plan, of purpose, and harmony of parts, and it sceks for its adventures among the wild and wonderful. It does not confine itself to what is known, or even what is probable. It grasps at the possible; and, placing a human agent in hitherto untried situations, it exercises its ingenuity in extricating him from them, while describing his feelings and his fortunes in his progress. The task has been well or ill done, in proportion to the degree of ingenuity and knowledge which the romancer exhibits in carrying out the details, according to such proprieties as are called for by the circumstances of the story. These propricties are the standards set up at his starting, and to which he is required religiously to confine himself.

'The Yemassee' is proposed as an American romance. It is so styled as much of the material could have been furnished by no other country... The natural romance of our country has been my object, and I have not dared beyond it..." (S. 5-6: "To Professor Samucl Henry Dickson, M.D., of South Carolina"); vgl. auch dic anderen Romantitel von Simms: Guy' Rivers (1834), Richard Hurdis (1838), Border Beagles (1840), Beaucbampe (1842), Helen Halsey; or, The Swamp State of Corelacbita (1845), The Wignam and the Cabin (1845-46), Charlemont (1856), The Cassique of Kiawah (1859), Voltmeier; or, The Mountain Men (1869), The Club of the Panther, A Mountain Legend (1869). 
dings blieben die oberen Etagen der Literatur dem Western verschlossen mit Ausnahmen bis auf den heutigen Tag. Das liegt nicht zuletzt an der ursprünglichen Einschätzung der amerikanischen romance durch die das geistige Klima bestimmende literarische Elite. Simms hatte den Fehler gemacht, das "Amerikanische" rein inhaltlich-thematisch zu bestimmen: amerikanische Literatur mußte demnach von amerikanischen Gegenständen handeln. Dem konnte man mit Recht entgegenhalten, daß auch Literatur über andere Gegenstände "American spirit" beweisen könne. Die nationalistische bzw. patriotische Verengung des Blickfeldes führte zu literarischer Ghettobildung und Provinzialismus. Das Schicksal der Western Novel war es, mit diesem Schreckgespenst schon vor ihrer eigentlichen Entstehung assoziiert $\mathrm{zu}$ werden und zu bleiben.

Schon vor der Blütezeit der Dime Novel gab es amerikanische Erzählliteratur, die nicht in bard covers verkauft werden konnte; die eigentlichen Americana galten offenbar von vornherein als "cheap literature," hatten also ein Stigma, das den Aufstieg in die höhere Literatur versperrte. Große Bestände von Coopers Lederstrumpf-Romanen mußten zwischen 1839 und I 843 aus den Leineneinbänden geschnitten und mit "paper covers" versehen werden, da sie unverkäuflich waren, als Paperbacks aber einen Markt fanden. ${ }^{40}$ Die Käufer dieser Literatur waren also damals - wie heute - nur teilweise identisch mit den Käufern von leinengebundenen Büchern. Zu der seit Jahrhunderten literaturtragenden Schicht des bürgerlichen Mittelstandes waren neue Schichten getreten, die bis dahin weder gelesen noch Bücher gekauft hatten. Entsprechend änderten sich die Verlags- und Verkaufspraktiken. Es wurde nicht mehr eine kleine, privilegierte Oberschicht von Lesern angesprochen, sondern ein breites, weder durch Schicht, Klasse, Generation, Geschlecht oder Besitz differenziertes Publikum.

Während die amerikanischen Intellektuellen Literatur weiterhin mit dem Osten des Landes assoziierten - wenn nicht sogar an England dachten -, verbreitete sich der Western in Form der Dime Novel in allen Schichten der Bevölkerung, die kurzweilige Unterhaltung suchten. Neben Unterhaltung bot diese Literatur jedoch auch Leitbilder und suggerierte ein neues Selbstverständnis. Nicht zuletzt aus diesem Grunde sind die Dime Novels für uns bedeutsam. Sie bringen exemplarisch-allgemeingültig Aussagegehalt und Bedeutung des Westens für das amerikanische Leben auf eine Formel, und zwar sowohl im Sinne der literatursoziologischen reflection theory als

${ }^{40}$ Ein Grund dafür dürfte wohl darin zu suchen sein, daß der damalige Buchmarkt durch preisgünstige Romanbeilagen von Zeitschriften bestimmt wurde. Bezeichnenderweise ist Beadles erste Dime Novel (Ann Sophia Stephens, Malaeska: The Indian Wife of the White Hunter) zuerst in einer Zeitschrift (The Ladies' Companion, Februar bis April 1839) erschienen. Vgl. Madelaine B. Stern, "The First Beadle Dime Norel and Its Author," American Book Collector, I4, 2. Heft (1963), 27. 
empirisch-erarbeitetes Bild von amerikanischen Reaktionen wie auch als eigenständige Schaffung bzw. Zerstörung von Mythen. ${ }^{41}$

Als exemplarische Romane stehen die Dime Novels bereits auf einer beträchtlich hohen Abstraktionsstufe. Geschichte ist als solche nicht darstellbar, jedenfalls nicht für den Schriftsteller - es sei denn durch Sichtung und Ordnung der chaotischen Fülle des Stoffes und der Ereignisse mit dem Ziel, Linien, Tendenzen und Bedeutungen erkennbar zu machen.

Daher wird Geschichte von den Autoren auf die Taten eines Mannes reduziert, der dann prototypisch für seine Zeit steht. Das mag auf anekdotische Weise geschehen, durch typisierende bzw. exemplarische Darstellung, in Form einer pikarischen Geschichte oder eines Entwicklungsromans. Jedenfalls stehen immer Individuen für historische Epochen, Gruppen, Klassen, Rassen, die frontier bzw. irgendwelche antagonistische Parteien. Sie stellen somit eine Art Formalisierung bzw. Konzeptualisierung von Geschichte dar. In diesem Sinne hat auch das stark stereotype Klischee seinen Sinn und seine Bedeutung: es fungiert als eine Art Allgemeinbegriff, der eine große Fülle von Einzelheiten nach Art eines Abkürzungsverfahrens des Geistes aufnimmt und für sie eintritt. Auch das historische Klischee (Kit Carson, Buffalo Bill, General Custer) ist formalisierte Geschichte, letzte Stufe eines Abstraktionsprozesses und daher für Literaturwissenschaftler und Historiker gleich bedeutsam.

Dabei ist nicht einmal von ausschlaggebender Bedeutung, daß die Formel der historischen Wirklichkeit entspricht, da diese Wirklichkeit im Detail ohnedies nicht mehr greifbar und darstellbat ist. Somit können auch gänzlich unhistorische Figuren solche Funktionen übernehmen, wie z. B. der Virginian, ${ }^{42}$ der durch die Massenmedien zu dem prototypischen Cowboy geworden ist. ${ }^{43}$ Dargestellt wird im Western und in der Captivity letztlich der Kampf des Menschen gegen das Unbekannte und gegen das feindliche Prinzip in der Natur und in der Gesellschaft.

Es ist daher zu Recht festgestellt worden, ${ }^{44} \mathrm{da} B$ die Western Novel Parallelen und Ähnlichkeiten zum mittelalterlichen Morality Play aufweist, in dem gute und böse Engel um die Seele des Menschen kämpfen. Die Kräfte des Guten gewinnen, und die Zivilisation gewinnt, selbst wenn das im Leben leider nicht immer der Fall ist. Es geht nicht um einzelne, vielleicht wahre historische Ereignisse, sondern um die psychologisch notwendige Darstellung des Sinnes hinter den Ereignissen. Die Geschichte ${ }^{41}$ Vgl. dazu Robert H. Walker, "The Poets Interpret the Western Frontier," Mississippi Valley Historical Review, 47 (1960/61), 619-635, hier: S. 619.

${ }^{42} \mathrm{Vgl}$. Owen Wister, The Virginian. A Horseman of the Plains (1902).

${ }^{43} \mathrm{Vgl}$. dazu Kent Ladd Steckmesser, The Western Hero in History and Legend (1965).

${ }^{14}$ Howard C. Brashers, "The Cowboy Story from Stereotype to Art," Moderna Strak, 57 (1963), 290-299. 
selbst ist allegorisch angelegt, und Gegenstand der Allegorie ist der Triumph des Guten.

Die Dime Novel richtet sich also keineswegs an die untersten Bevölkerungsschichten, wie des öfteren behauptet worden ist. Manchmal wird sie gar "proletarian literature" 45 genannt, obwohl Klassenprobleme wie überhaupt gesellschaftliche Fragen in der Dime Novel kaum eine Rolle spielen. Es geht vielmehr ganz generell um Abenteuer, insbesondere die des frontiers man an der Grenze zwischen Wildnis und Zivilisation und damit um einen für das amerikanische 18 . und 19 . Jahrhundert entscheidend bedeutsamen und kennzeichnenden Zug. Auch in England und Deutschland wurde zu dieser Zeit Abenteuerliteratur geschrieben und gelesen. Ihr charakteristisches Merkmal ist Eskapismus im Sinne von Darstellung einer außerhalb der gesellschaftlichen Wirklichkeit zu suchenden neuen Erlebnisdimension.

In Amerika aber gehörte die frontier und der mit ihr notwendigerweise verbundene Individualismus zu den formenden Kräften der alltäglichen Wirklichkeit und damit zu einem das gesellschaftliche Leben bestimmenden, zumindest aber beeinflussenden Faktor. ${ }^{46}$ Der Begriff "frontier" ist unpräzise, weil er zumindest bei einem Europäer falsche Assoziationen auslöst. Wir denken dabei an eine auf der Karte absteckbare Linie, die ähnlich wie die Schützengräben von Osten nach Westen vorverlegt wird, an eine klar definierbare Grenze zwischen zwei Landesteilen oder zwischen Barbarei und Zivilisation. Daraus ergibt sich die Vorstellung von einer kollektiven und organisierten Verschiebung der Grenzlinie. Tatsächlich wurden die Siedler zwar offiziell ermutigt, nach Westen zu ziehen, aber ebenso oft von Regierungsseite auch gewarnt. Der einzelne Treck kam immer durch Privatinitiative zustande, das frontier-Erlebnis ist etwas zutiefst Individuelles, die Konfrontation mit dem Ungewissen und somit dem Abenteuer seitens der Einwanderer, die meist aufgrund von Unfreiheit und Unterdrückung oder auch nur wegen Armut ihr Heimatland verlassen hatten. Der Held der Dime Novel ist der Selfmademan.

Daher ist in diesen Geschichten nicht von Rittern, Adligen, Gutsbesitzern etc. die Rede, sondern von tapferen, unbeugsamen Streitern, die von der Prämisse ausgehen, daß ein richtiger Mann durch Tatkraft und Verstand jedes Hindernis aus dem Wege räumen kann. Zwar konnten auch englische Adlige zu dieser Gruppe von Menschen gehören, aber das blaue Blut spielte keine auszeichnende Rolle mehr. An der frontier kam es auf andere Eigenschaften und Fähigkeiten als die vom Adel in Europa kulti-

${ }^{45}$ Merle Curti, "Dime Novels and the American Tradition," Yale Review, 26 (1936/37), 76r.

${ }^{46} \mathrm{Vgl}$. dazu u. a. die Schriften von Frederick Jackson Turner: The Significance of the Frontier in American History (1893), Rise of the New West, I819-1829 (1906), The Frontier in American History (1920). 
vierten an. Das bedeutet keineswegs, daß alle Menschen an der frontier gleich waren. Alle hatten lediglich gleiche Chancen, und daraus resultierte, wit wir von Owen Wister hören, das Evangelium der ewigen Ungleichheit der Menschen. ${ }^{47}$

Es ist daher falsch, vom "cult of the plain people" 48 zu sprechen. Wenn es überhaupt einen Kult gab, dann den des Tüchtigeren, Stärkeren, des Überlegenen, des Mannes, der der Wildnis und den Indianern trotzen konnte, der Garant war für das Fortbestehen der Zivilisation des weißen Mannes in einer feindlichen Umwelt.

Dabei spielten die alten sozialen Rangunterschiede keine Rolle mehr. Der Grund dafür liegt darin, daß neue, für den Kampf an der frontier relevante Unterschiede gesellschaftsbestimmend wurden. $\mathrm{Da} B$ der Protagonist Seth Jones $^{49}$ sich zum Schluß auch noch als Gentleman entpuppt, ist eine zusätzliche Pointe. Für den Gang der Handlung ist bedeutsam, daß er den Indianern auf deren Gebiet überlegen ist, schießen kann, Ausdauer und außerdem noch Verstand besitzt.

Wenn Engländer oder Tories in der Dime Novel negativ beurteilt werden, so geschieht das kaum aus Gründen der Klassenzugehörigkeit, sondern

47 "'I'll tell you what', pursued the cow-puncher [= the Virginian] with slow and growing intensity, 'equality is a great big bluff...' ‘... Wait, and let me say what I mean...' '. .. I know a man that works hard and he's gettin' rich, and I know another that works hard and is gettin' poor. He says it is his luck. All right. Call it his luck. I looked around and I see folks movin' up or movin' down, winners or losers everywhere. All luck, of course. But since folks can be born that different in their luck, where's your equality? No, seh! call your failure luck, or call it laziness, wander around the words, prospect all yu' mind to, and yu'll come out the same old trail of inequality.' '... Some holds four aces', he went on, 'and some holds nothin', and some poor fello' gets the aces and no show to play ' $\mathrm{em}$; but a man has got to prove himself my equal before I'll believe him." Owen Wister, The Virginian. A Horseman of the Plains (1902, repr. 1967), S. 122f. "There can be no doubt of this:- All America is divided into two classes, - the quality and the equality. The latter will always recognize the former when mistaken for it. Both will be with us until our women bear nothing but kings.

It was through the Declaration of Independence that we Americans acknowledged the eternal inequality of man. For by it we abolished a cut-and-dried aristocracy. We had seen little men artificially held up in high places, and great men artificially held down in low places, and our own justice-loving hearts abhorred this violence to human nature. Therefore, we decreed that every man should thenceforth have equal liberty to find his own level. By this very decree we acknowledged and gave freedom to true aristocracy, saying, 'Let the best man win, whoever he is.' Let the best man win! That is America's word. That is true democracy. And true democracy and true aristocracy are one and the same thing. If anybody cannot see this, so much the worse for his eyesight." Owen Wister, a.a.O., S. I 25. Hervorhebung original.

${ }^{48} \mathrm{Vgl}$. Merle Curti, a.a.O., S. 765.

${ }^{49}$ Edward S. Ellis, Seth Jones; or, The Captives of the Frontier (1860). 
weil das Wertsystem der frontier anders aufgebaut ist. Die jungen Mädchen der Siedler müssen z. B. von ihren künftigen Ehemännern verlangen, daß sie Familie und Land beschützen und verteidigen können. Blut und Herkunft sind ihnen daher genauso gleichgültig wie vornehme Sitten, Kleidung und gepflegte Redeweise. Die amerikanische Revolution wird in der Dime Novel geradezu als Bewegung angesehen, die zu einer vernünftigen und natürlichen Bewertung des einzelnen Menschen hinführt und überholte Maßstäbe über Bord wirft.

Die überaus starke Betonung der individuellen Freiheit führte im Extrem zu gesellschaftsfeindlicher Anarchie und zum Chaos. Ausdruck dieser Freiheit in der Realität wie in der Fiktion ist die Anwendung von Gewalt. Sie ist letzte Stufe der Individualität, im Roman sogar nicht selten folgerichtiges Ergebnis des frontier-Erlebnisses, d. h. der Abkehr von alten gesellschaftlichen Normen und Rechtsprinzipien, die sich als nicht mehr anwendbar erwiesen. Wenn Präsident Monroe und der Kongreß das Land der Indianer enteigneten und ganze Völker verjagten, ${ }^{50}$ geschah auf höchster Ebene ähnliches, wie wenn ein Trapper einen unerwünschten Nebenbuhler im Walde erschoß und ihm die Felle abnahm.

Anarchische Gewalt kennzeichnet viele Dime Novel-Helden. Sie ist letzte Stufe der Rebellion gegen die organisierte Gesellschaft, gleichzeitig aber auch Selbsterfüllung des Individuums, das nicht nur sein eigenes Schicksal, sondern auch das anderer Menschen in die eigene Hand nimmt. Dabei ist von untergeordneter Bedeutung, daß es in den meisten Fällen um Beseitigung vermeintlicher Ungerechtigkeit oder um Rache geht. Wichtig ist, daß der Einzelne zum Sheriff, Richter oder Henker wird und dabei jedes Korrektiv ausgeschaltet wird. ${ }^{51}$

Der eigentümlich schillernde Charakter dieser Literatur aber ergibt sich aus der gleichzeitig vorhandenen entgegengesetzten Tendenz. Die kolonialen Amerikaner hatten ein tiefes Mißtrauen gegenüber dem Individuum und seinen Bedürfnissen, insbesondere gegen eine zu rasche Bedürfnis-

${ }^{50}$ Vgl. dazu Western Scenes and Reminiscences together with Thrilling Legends and Traditions of the Red Men of the Forest (1853), S. 366, und einen Artikel in der Democratic Review von 1844 , "The Fate of the Red Race in America: The Policy Pursued towards Them by the Government, and the Present Condition of the Tribes Who Have Removed West of Mississippi." In diesem Artikel werden die Weißen = Teutonen als rassisch überlegen bezeichnet. Aufgabe, "object" dieser Rasse ist es, "to carry on man to his highest destiny" (S. 367-68). "We consider the Pilgrims as the embodiment of the true ancient Teutonic type" (S. 368). "Placed side by side with such an enlightened and purposed race, what had the priests of the system of native rites and superstitions to expect? ... no compromise ... no toleration ... no conformity" (S. 369).

${ }^{51}$ Vgl. Daryl E. Jones, "Blood'n Thunder: Virgins, Villains, and Violence in the Dime Novel Western," Journal of Popular Culture, 4 (1970/71), 507-517. 
befriedigung. Das gilt für Sexualität, Alkohol, Nikotin sowie für manche Annehmlichkeiten des Lebens, die den Puritanern suspekt waren; es gilt aber auch für Macht und Machtausübung. Zwar sind patriotische amerikanische Historiker nicht damit einverstanden, Tatsache scheint aber doch, daß die Amerikaner dem nicht Anpassungswilligen, dem Einzelgänger, der nicht integriert werden konnte, mißtrauten. Dem Einzelgänger bedeutet die Gemeinschaft nichts. Es ist daher kein Wunder, daß die Gemeinschaft den Einzelgänger ablehnt bzw. zu absorbieren sucht.

$\mathrm{Zu}$ den als überholt angesehenen Normen gehören vor allem die ererbten Privilegien des Blutes und der Herkunft. Die Darstellung von Indianern (und Schwarzen) zeigt aber, daß die Autoren bei der Verteilung der Grundrechte recht selektiv und gar nicht demokratisch vorgingen. Sowohl Indianer als auch Schwarze wurden von den Dime Novel-Autoren als rassisch unterlegen angesehen. ${ }^{52}$

Die Politik gegenüber den Indianern war seit 1825 nicht mehr umkehrbar. Präsident Monroe selbst hatte die Weichen gestellt für die Auslöschung bzw. Vertreibung der Indianer und damit eine Lösung des Indianerproblems, ${ }^{53}$ die so unmenschlich und brutal war, daß die Amerikaner selbst heute nicht gern daran erinnert werden. Die Politiker bürdeten damit dem amerikanischen Gewissen eine ungeheure Last auf. Wo immer wir seit Cooper von Indianern lesen, spüren wir dieses schlechte Gewissen dem roten Mann gegenüber, der einst das Land besessen hatte und der vertrieben oder getötet worden war, weil er anders leben wollte als die Weißen. Daher liegt der. Gedanke nahe, daß auch die literarischen Darstellungen des "roten Wilden" und seiner Grausamkeiten nur eine Art Rechtfertigung oder Alibi der Weißen sind, die genau wußten, daß ihr Vorgehen gegenüber den Eingeborenen mit eigenen moralischen Maßstäben nicht zu rechtfertigen war.

Häufiger als der "edle Wilde" ist in der Literatur daher der grausame Wilde anzutreffen. Er wird meist topisch dargestellt; die Merkmale wurden

52 "When the Anglo-Saxon's body is pitted against that of the North American Indian, it sometimes yields; but when his mind takes the place of contestant, it never loses." E. S. Ellis, Seth Jones; or, The Captives of the Frontier, ed. P. Durham, zus. mit E. L. Wheeler, Deadwood Dick on Deck, Popular American Fiction, Dime Novels (1966), S. 27.

${ }^{53}$ Vgl. dazu die Erklärung des Präsidenten (1 825): "Experience has clearly demonstrated that, in their [= the Indians'] present state, it is impossible to incorporate them, in such masses, in any form whatever, into our system. It has also demonstrated, with equal certainty, that without a timely anticipation of, and provision against, the dangers to which they are exposed, under causes which it will be difficult, if not impossible, to control, their degradation and extermination will be inevitable." Zit. in: Roy Harvey Pearce, The Savages of America. A Study of the Indian and the Idea of Civilisation (1953), S. 375. 
aus den Captivities übernommen, so z. B. in der bekanntesten Dime Novel von Ellis, Seth Jones. ${ }^{54}$

Natürlich wurden die Indianer keineswegs immer und von jedermann verteufelt. ${ }^{55}$ Es gab auch eine primitivistische Traditionslinie, die im Indianer den edlen Wilden sieht, den "gentleman of nature," den die Natur zu höchster menschlicher Vollkommenheit geläutert hat. Einen solchen Wilden finden wir etwa in Malaeska ${ }^{56}$ oder in Unca Eliza Winkfields The Female American. ${ }^{57}$ Der Erzähler der Geschichte, Sohn aus einer gemischten Ehe, schlägt die ihm angebotene Rückkehr nach England aus, weil er bei den menschlich wesentlich höher eingeschätzten Wilden leben will. Ähnlich positiv ist das Bild des Indianers in den Werken von Freneau. ${ }^{58}$ Der Indianer wird hier als moralisch überlegen dargestellt; die christliche Erziehung jedoch verdirbt und unterminiert nach Auffassung Freneaus den ursprünglichen natürlichen Adel. Die genannten Werke Freneaus sind im I8. Jahrhundert entstanden, d. h. also etwa siebzig Jahre bevor die Dime Novel ihren Siegeszug antrat. In der Mitte zwischen den Extremen steht J. F. Cooper. Für ihn kann der Indianer gleichermaßen edel und bösartig sein. In den Lederstrumpf-Romanen degenerieren zunächst Seelenadel und Größe des Stammes und danach des Individuums. Die Perversion der indianischen Tugenden erfolgt bei Cooper durch das Eindringen merkantiler, ökonomischer Gesichtspunkte aus der westlichen Welt. Cooper beklagte den Untergang eines edlen, wilden Volkes, das den Lebensgewohnheiten des weißen Mannes zum Opfer fiel.

Die Darstellung der Roten in den Dime Novels ist vielleicht das am we-

\footnotetext{
54 S. Fußnote 50.
}

${ }^{55}$ Kaum jemals brauchen die Leser z. B. um die von Indianern geraubten Mädchen Angst zu haben; natürlich werden die Armen gelegentlich gefoltert und gequält. Es ist aber in der gesamten Dime Novel-Literatur kein Fall bekannt, daß auch nur eine einzige ihre Virginität eingebüßt hätte - und das wäre damals fast schlimmer gewesen als das Leben zu verlieren. Recht häufig dagegen wird erzählt, daß weiße Mädchen Indianer heirateten -- und zwar aus freien Stücken!, oder daß sie nicht mehr zu Freunden und Verwandten zurück wollten, weil sie das freie Indianerleben vorzogen.

${ }^{56}$ Ann Sophia Stephens, Malaeska, The Indian Wife of the White Hunter (1860, repr. I929, repr. 1971).

${ }^{57}$ The Female American; or, The Extraordinary Adventures of Unca Eliza Winkfield, comp. by herself (1 814).

58 Philip Freneau, "The American Village" (1772); "The Indian Convert" (1 797); "The Indian Student" (1 788); “The Indian Burying Ground" ( 1787 ), "The Dying Indian, Tomo-Chequi" ( 1784 ); "The Splenetic Indian," in: Miscellaneous Works (1 788), "The Prophecy of King Tammany" (1 782): vgl. dazu P. M. Marsh, Pbilip Freneau, Poet and Journalist (1967), S. I 28-139, und v.a. das Kapitel "The Indian Comes into His Own" in: A. Keiser, The Indian in American Literature (1933), S. 21-32. 
nigsten befriedigende, eigentlich sogar deprimierende Merkmal dieser Literatur. Wird in den Romanen um I 830 wenigstens noch begründet, warum die Indianer feindselig sind (nämlich weil sie immer weiter in das Innere des Landes zurückgedrängt worden sind, ihte Jagdgründe aufgeben und befürchten mußten, das ganze Land an die Weißen zu verlieren), so fehlt diese Begründung in den späteren Dime Novels völlig. Es sieht immer mehr so aus, als neideten die Indianer aus bloßer Mißgunst oder Bösartigkeit den Weißen das Land. Über die Motive der Indianer wird in den Dime Novels nicht mehr nachgedacht. Der Rote steht einfach für Unkultur und Barbarei; er muß vernichtet werden, da er den Fortschritt aufhält.

Zum Beleg der feindseligen Haltung gegenüber den Indianern könnten sehr viele Indianergeschichten herangezogen werden, die in Dime NovelForm zwischen I 860 und $189 \circ$ geschrieben worden sind. Das zunächst recht differenzierte Bild der Roten wird allmählich zum Klischee. Gutes wissen die Autoren über die Indianer nicht mehr zu sagen, wahrscheinlich auch im Hinblick auf das Lesepublikum, das immer stärker dahingehend indoktriniert worden war, im Indianer den Feind und den Teufel zu sehen, sicherlich aber auch aufgrund einer literaturimmanenten Trivialisierung des Genre und der damit einhergehenden Tendenz zur Schwarz-Weiß-Malerei und Typisierung. Sicherlich gibt es auch während dieser drei Jahrzehnte Ausnahmen, Autoren, die sich um ein besseres Verständnis der Indianer bemühten und in ihren Romanen Menschen von Fleisch und Blut und nicht einfach Teufel darstellten. Eine Tendenzwende ist aber erst im letzten Jahrzehnt des Jahrhunderts zu erkennen, nach Beendigung der Indianerkriege, d. h. nachdem das Schicksal der roten Rasse in Amerika so gut wie besiegelt war.

$\mathrm{Daß}$ gegen Ende des 19. Jahrhunderts eine Wandlung im Verhältnis zu den Indianern einsetzt, die bis ins 20. Jahrhundert reicht, kann aus der Dime Novel-Literatur nachgewiesen werden. Das liegt natürlich in erster Linie daran, daß die frontier geschlossen war und es kein weiteres Land mehr zu erobern gab. Die Indianer waren ausgelöscht oder vertrieben worden und stellten keine ernsthafte Bedrohung mehr dar. Zwar bereiteten sie immer noch Schwierigkeiten, aber nur noch örtlicher Art: das Indianerproblem war gelöst.

Damit verschwand der zur Pionierzeit vorherrschende Impetus zur Selbstbehauptung und -durchsetzung gegenüber einem ernstzunehmenden Gegner, und es setzte sich die Vorstellung durch, daß die Indianer von vornherein auf verlorenem Posten gestanden hatten und mit Würde und Haltung untergegangen waren. Natürlich ist die in den neunziger Jahren beginnende Rehabilitierung des Indianers vor allem motiviert durch das schlechte Gewissen des Amerikaners. Die Autoren kommen nach Art einer psychologischen Zwangshandlung immer wieder auf das Problem des 
Völkermordes an den Indianern zurück, suchen sich zu rechtfertigen, die Gewichte gerecht zu verteilen oder aber durch Eingestehen der Schuld zu später Wiedergutmachung anzuleiten. ${ }^{59}$

Größere Entwicklungslinien der Dime Novel können beim augenblicklichen Wissensstand noch nicht gezogen werden. Da die Dime Novel historisch in eine Phase sprunghafter Entwicklung und Industrialisierung fällt, ist jedoch anzunehmen, daß sie soziale Entwicklungstendenzen widerspiegelt. Wenn z.B. gegen Ende der Dime Novel-Phase die Indianer keine wesentliche Rolle mehr spielen und seitens der Autoren durch Diebe, Mörder, Wegelagerer und andere Bösewichte ersetzt werden, so liegt das daran,

${ }^{59}$ Ein typisches Beispiel ist Edward S. Ellis, dessen späte Werke offensichtlich bisher nicht untersucht worden sind. Während Ellis in Seth Jones den üblichen, fast stereotypen Indianerhaß an den Tag legt, sind seine Werke ab I 890 durch ein ausgewogenes Verhältnis zu den Roten gekennzeichnet. In seiner sehr lesenswerten Geschichte der Indian Wars setzt er sich zunächst von denen ab, die entweder alle Schuld bei den Roten oder bei den Weißen suchen. Ellis möchte zu einem ausgewogenen Urteil anleiten: "We have two classes of extremists: those who maintain that there is only one good Indian and he is dead, and those who believe that the red man has been the invariable victim, instead of the wrongdoer, in all the troubles of the white men with his people. That the latter has been the truth in a majority of instances is undeniable, but it is equally true that more than once the treachery, the cruelty, and the atrocity of the Indian have had no shadow of palliation or excuse. The Indian problem still confronts us, but a knowledge of our history ... must enable all to read the true answer to the question which has caused the waste of so much treasure and life." (Edward S. Ellis, The Indian Wars of the United States. From the first settlement at Jamestown, in 1607 , to the close of the great uprising of $1890 / 91$ [1892], S. III).

Sein eigenes Verdikt aber ist ganz eindeutig: die Indianerkriege sind ein Schandmal für die Nation: "The history of the Indian wars of the United States is a history of one continuous series of blunder, frauds, oppressions, injustice, and crime that is a reproach to our nation. Here and there, in the record, a bright page shines out all the more vividly because of its contrast with the surrounding darkness. None can estimate the amount of property destroyed, the number of lives sacrificed, and the injury done to civilization and progress by our dealings with the Indians" (Ebd., S. III). Zu einer ähnlichen Position gelangte allerdings auch der Romancier Ellis. Er hat um die Jahrhundertwende eine Reihe von Büchern geschrieben, in denen die Indianer zwar auch noch Wilde sind und Grausamkeiten begehen, gleichzeirig aber auch positive Helden sind. Ein Zitat aus Iron Heart. War Chief of the Iroquois ( 1900 ) kann das neue Verhältnis zu den Indianern exemplarisch verdeutlichen:

" 'Iron Heart comes to his paleface brother and tells him he will be his brother. The huniing grounds are broad enough for the white and the red men, and the Great Spirit wishes them to live in peace. Let us be brothers.'

General Greenfield stepped impulsively forward and extended his hand. His eyes were moist, as he said: 'The words of Iron Heart have sunk deep in my heart; they make me glad; we shall be brothers. Let Iron Heart go back to his warriors and tell them that the palefaces will be their friends" (S. ${ }_{3} 83$ ). 
daß der Indianer für das Leben des A merikaners nicht mehr von Belang war.

Änderungen sind auch im Verhältnis zur Frau, zu Recht, Gesetz und Gesellschaft festzustellen. Nachdem es keine frontier mehr gab, kehrte sich die Tendenz der populären Unterhaltungsliteratur um: statt der Wildnis wurde nun ausschließlich die Stadt erobert, ${ }^{60}$ und zwar von Detektiven, "private operators" und Polizisten. Je weniger unberührte Wildnis es draußen in der Natur gab, desto üppiger wucherte sie in den Städten, die bald als ebenso bedrohlich und unheimlich empfunden wurden wie zuvor der Urwald. Horatio Alger schuf einen neuen Typ von Geschichte: die vom country boy, der sich die Stadt erobert. ${ }^{61}$ Der Held ist zunächst der "thumbe thor," der auf dem Lande nur mit rechtschaffenen, aber einfältigen Leuten in Berührung gekommen war und daher erst lernen muß, daß in der Stadt andere Maßstäbe gelten. Durch Tüchtigkeit und eine gehörige Portion Intelligenz findet er sich aber nicht nur schnell zurecht, sondern macht zudem Karriere. Auch in dieser Literatur wird ein Klischee geprägt, das teilweise noch heute das Bild von Amerika bestimmt: es ist das Land der tausend Möglichkeiten, wo auch der Schuhputzer und der Tellerwäscher zum Millionär werden kann.

Wenn den jungen Leuten gesagt wurde, daß ihnen in den Städten alle Möglichkeiten offen stünden, so ist das eine offensichtliche Parallele zur frontier-Zeit, als das offene Land eine ähnliche Aufforderung darstellte. In beiden Fällen handelt es sich um das Thema "self help" und "self reliance," das als "Thema mit Variationen" während der ganzen Dime Novel-Blütezeit erkennbar war. Hilf dir selbst, so hilft dir Gott - diese Formel ist von den amerikanischen Autoren ganz wörtlich genommen worden. In den Dime Novels über das städtische Leben wird nämlich keineswegs dargestellt, wie ein armer Junge durch Fleiß, Ehrlichkeit und ähnliche Mittelklassetugenden reich wird. Diese Eigenschaften sind nur Voraussetzung für den "lucky break:" eine Erbschaft, Schenkung, Lotteriegewinn, Adoption durch Millionär usf.

${ }^{60}$ Bereits George Lippard hatte allerdings die Stadt in seinen Sensationsromanen Quaker City; or, The Monks of Monk Hill (1844) und New York: Its Upper Ten and Lower Million (1853) entdeckt.

${ }^{61} \mathrm{Vgl}$. dazu u.a. folgende Titel aus der Feder von Horatio Alger: Struggling Upward, or, Luke Larkin's Luck; Ragged Dick, or, Street Life in New York; Phil, the Fiddler, or, The Young Street Musician; Jed, the Poorbouse Boy. Diese vier Geschichten, hrsg. von R. Crouse, u.d. Titel Struggling Upward (r 945), stellen nur einen winzigen Bruchteil dessen dar, was Horatio Alger tatsächlich geschrieben hat; vgl. dazu die Liste der Titel von R.Crouse, a.a.O., S. 568-570, die - ohne Anspruch auf Vollständigkeit zu erheben - I 35 Titel umfaßt. - Zum Phänomen des country boy, der sich die Stadt erobert, vgl. John G. Cawelti, Apostles of the Selfmade Man (1965), Kp. IV, S. I or ff. 
Diese Art von Literatur scheint besonders zeitgebunden. Etwa ab I 900 konnte man als Schuhputzer selbst in New York nicht mehr reich werden. Das Klischee lebte jedoch noch zwanzig bis dreißig Jahre in der Literatur weiter. Ein sehr viel zäheres Leben dagegen hat der Western, der heute noch so beliebt ist wie zur Dime Novel-Zeit. Auch für den Western sind Entwicklungstendenzen festgestellt worden. Die bisher vorgelegten Thesen bzw. Hypothesen bezüglich der Entwicklung des Helden vom historischen Cowboy zur mythischen Figur ${ }^{62}$ werden durch die Dime Novel widerlegt. Buffalo Bills Laufbahn ist auch heute noch nicht beendet - noch in den fünfziger Jahren erschienen Serien von Buffalo Bill-Heften in Deutschland, und erfundene Protagonisten stehen am Anfang der meisten Dime NovelSerien. Genauso fragwürdig ist die Behauptung, die Entwicklung gehe einerseits von moralischer Integrität zur Verachtung für das Gesetz und führe andererseits zur Kanonisierung von Verbrechern wie Jesse James, Billy the Kid usf. Der Prozeß der Heroisierung und Mythisierung solcher Helden (in Analogie zu Robin Hood) ist nicht auf eine so einfache Formel zu bringen. Die Geschichte des Western muß noch geschrieben werden.

${ }^{62} \mathrm{Vgl}$. dazu: Russel B. Nye, "The Juvenile Approach to American Culture, I 870-1930," in: Ray B. Browne et al., edd., New Voices in American Studies, Purdue University Studies (1966), S. 67-84, und: ders., The Unembarrassed Muse: The Popular Arts in America (1970). 